\title{
A US\$ 1 Trillion Question: Is The Current Chinese Exchange Rate Regime Sustainable?
}

\section{A. Laure Baldi-Delatte}

\section{Q OpenEdition}

1 Journals

Édition électronique

URL : http://journals.openedition.org/chinaperspectives/1046

DOI : 10.4000/chinaperspectives.1046

ISSN : 1996-4617

Éditeur

Centre d'étude français sur la Chine contemporaine

\section{Édition imprimée}

Date de publication : 1 octobre 2006

ISSN : 2070-3449

Référence électronique

A. Laure Baldi-Delatte, «A US\$ 1 Trillion Question: Is The Current Chinese Exchange Rate Regime Sustainable? », China Perspectives [En ligne], 67 | september-october 2006, mis en ligne le 01 juin 2007 , consulté le 28 octobre 2019. URL : http://journals.openedition.org/chinaperspectives/1046 ; DOI : 10.4000/chinaperspectives. 1046

Ce document a été généré automatiquement le 28 octobre 2019.

(C) All rights reserved 


\section{A US\$ 1 Trillion Question: Is The Current Chinese Exchange Rate Regime Sustainable?}

\section{A. Laure Baldi-Delatte}

\section{RÉSUMÉS}

The recent surge in China's foreign exchange reserves (one trillion US\$ in October 2006), is behind this update analysis of the domestic issues that it raises. The speculation on a future appreciation of the yuan has recently boosted money growth in China. Some controls on capital inflows reduced short-term capital in 2005 and 2006 but this has been compensated for by a surge in the trade surplus. This has resulted in abundant liquidity in China responsible for distortions which this article endeavours to analyse.

INDEX

Thèmes : economie 